\title{
Stability of pyrochlore and trace element partitioning in carbonatitic systems
}

\author{
MARION LOUVEL ${ }^{1}$ AND STEPHAN KLEMME $^{2}$ \\ ${ }^{1}$ WWU Munster \\ ${ }^{2}$ Universität Münster \\ Presenting Author: louvel@uni-muenster.de
}

Rare earth (REE) and high-field strength elements (Nb, Ta, Zr) are critical metals for the development of modern greener technologies. The genesis of primary economic concentration of $\mathrm{REE}, \mathrm{Nb}$ and $\mathrm{Ta}$ in the Earth's crust depends on a combination of magmatic and hydrothermal concentration processes. In general, magmatic enrichment, through fractional crystallization of alkaline magmas, is a pre-requisite.

A main source of REE, $\mathrm{Nb}$ and associated $\mathrm{Ta}$ is found in pyrochlores (ideal formula: $\mathrm{Ca}_{2} \mathrm{Nb}_{2} \mathrm{O}_{7}$ ) from carbonatite and associated phoscorite deposits (e.g., Araxa and Catalao deposits, Brazil). Yet, the effect of pressure, temperature and composition on the formation of pyrochlore in carbonatite melt and its HFSE, REE, but also $\mathrm{U}$ and $\mathrm{Th}$ concentrations remain poorly constrained to date. Previous work by Mitchell and Kjarsgaard (2002, 2004) demonstrated that pyrochlore can be a liquidus phase in the simple system $\mathrm{CaCO}_{3}-\mathrm{NaNbO}_{3}-\mathrm{CaF}_{2}$, further suggesting extreme solubility of $\mathrm{Nb}(>10 \mathrm{wt} \%)$ above $900{ }^{\circ} \mathrm{C}$ at 1 kbar.

Following Mitchell and Kjarsgaard's work, we explored the crystallization of pyrochlore in carbonatitic systems of increasing complexity $\left(\mathrm{CaCO}_{3} \pm \mathrm{Na}, \mathrm{Mg}, \mathrm{F}, \mathrm{H}_{2} \mathrm{O}\right.$ but also $\mathrm{P}, \mathrm{Fe}$ and $\left.\mathrm{Si}\right)$ at $1100{ }^{\circ} \mathrm{C}$ and $10 \mathrm{kbar}$. Preliminary results suggest a strong effect of pressure and composition on the solubility of $\mathrm{Nb}$ in the carbonatitic melts. To complement this study, LA-ICPMS analysis will also be used to assess REE, HFSE, U and Th partitioning between pyrochlores and carbonatitic melts.

\section{References:}

Mitchell and Kjarsgaard, 2002. Contributions to Mineralogy and Petrology 144, 93-97.

Mitchell and Kjarsgaard, 2004. Contributions to Mineralogy and Petrology 148, 281-287. 